\title{
RECYCLING OF ASHES FROM FOREST BIOMASS COMBUSTION AS RAW MATERIAL FOR MORTARS
}

\section{RECICLAGEM DE CINZAS DA COMBUSTÃO DA BIOMASSA FLORESTAL COMO MATÉRIA-PRIMA PARA ARGAMASSAS}

REGINA CÉLIA ESPINOSA MODOLO, Dra. | UNISINOS

GUILHERME ASCENSÃO, Dr. | U AVEIRO

LUCIANO SENFF, Dr. | UFSC

FRANCISCO ROGER CARNEIRO RIBEIRO, M.SC. | UNISINOS

LUIS ANTÓNIO DA CRUZ TARELHO, Dr. | U AVEIRO

VICTOR MIGUEL FERREIRA, Dr. | U AVEIRO

JOÃO ANTÓNIO LABRINCHA, Dr. | U AVEIRO

ANTÓNIO SANTOS SILVA, Dr. | LNEC - Lisboa

CARLOS ALBERTO MENDES MORAES, Dr. | UNISINOS

\begin{abstract}
Rendering mortars were prepared by partially replacing conventional sands, namely coarse sand (CS) and fine sand (FS), by different dosages of biomass dry bottom ash (BA) and fly ash (FA). Bottom ash was treated by sieving and washing and called treated bottom ash (TBA). All these ashes were characterized, and their effects on the physical and mechanical characteristics of mortars were studied. The dosage of water required to maintain workability of samples formulated with TBA, BA, and FA was not considerably different from the volume used to formulate a reference mortar, since the physical characteristics of the ashes used were similar to those of CS and FS. Workability, weight variation, unrestrained shrinkage and compressive strength were measured. The mechanical and carbonation results showed that the pre-processing of BA and FA has to be properly characterized in the effort to reuse these materials as effective replacements of natural sand in mortars, and the associated environmental aspects should be further investigated to support this recycling strategy.
\end{abstract}

KEY WORDS: Bottom ash; Fly ash; Recycling; Mortars

\section{RESUMO}

As argamassas de revestimento foram preparadas substituindo parcialmente areias convencionais, nomeadamente areia grossa (AG) e areia fina (AF), por diferentes dosagens de cinzas secas de biomassa (CP) e cinzas volantes (CV). As cinzas pesadas foram tratadas por peneiração e lavagem e denominadas cinzas pesadas tratadas (CPT). Todas essas cinzas foram caracterizadas e seus efeitos sobre as características físicas e mecânicas das argamassas foram estudados. A dosagem de água necessária para manter a trabalhabilidade das amostras formuladas com CPT, CP e CV não foi consideravelmente diferente do volume utilizado para formular uma argamassa de referência, uma vez que as características físicas das cinzas utilizadas eram semelhantes às da AG e AF. Foram medidas a trabalhabilidade, variação de peso, retração livre e resistência à compressão. Os resultados mecânicos e de carbonatação mostraram que o pré-processamento de CP e CV deve ser devidamente caracterizado no esforço de reutilização destes materiais como substitutos eficazes da areia natural nas argamassas e os aspectos ambientais associados devem ser mais investigados para apoiar esta estratégia de reciclagem.

PALAVRAS-CHAVE: Cinzas pesadas; Cinzas volantes; Reciclagem; Argamassa 


\section{INTRODUCTION}

The need to reduce costs and controlling of anthropogenic gas emissions to the environment has led to a move towards replacing coal and petroleum products by alternative sources of energy (HINOJOSA et al., 2014, PALŠAUSKAS; PETKEVIČIUS, 2013). In view of this, biomass is one of the most interesting renewable natural resources in the production of various energy vectors because of the rising costs of fossil fuel, the hazards of nuclear energy, and the need to reduce carbono dioxide (CO2) emissions (CALLEJÓN-FERRE et al., 2014). In this sense, operational and environmental aspects of the ashes generated during the thermochemical conversion of biomass into energy are important factors in the development of reuse strategies (TARELHO et al., 2015).

According to Obernberger et al. (1997), the generation of sustainable strategy from biomass conversion requires closing material loops and integrating biomass ash to natural cycles. Approximately 480 million tons of ash are generated from biomass combustion worldwide annually (VASSILEV et al., 2013). But landfilling ashes from forest biomass combustion is subject to increasingly strict environmental regulations, such as management and proper disposal. This scenario represents an opportunity to investigate alternative recycling pathways for such waste (CHEAH; RAMLI, 2012, LABRINCHA et. al, 2014). ISO 14001/2015 defines environmental aspect as an element within an organization's activities, products, or services that interacts with the environment. In turn, environmental impact is described as any adverse or beneficial modification of the environment that results partially or totally from the environment aspects of the organization. According to Zobel et al. (2002), the identification and analysis of environmental aspects are essential elements in any environmental management system. Significant environmental aspects require previous characterization in the effort to develop the appropriate tools to implement environmental adjustments in the system and promote continuous improvement. These tools were classified by Höjer et al. (2008) as (i) procedural tools, which evaluate environmental impact and strategies and environmental management systems based on procedures and decision making processes; (ii) analytical tools, which are based on life cycle and material flow analyses considering the technical aspects of the analysis; and (iii) tools that comprise economic factors like cost-benefit analysis, life cycle cost as well as input and output analysis. Currently, the main criteria to assess significant environmental aspects and impacts include the probability, scale, severity, and duration of the impact as well as the difficulty to avoid it (ZOBEL et al., 2002).
According to Dahl et al. (2009) and Steenari; Fedje (2010), the characteristics of a given biomass vary with the species and its quality, influencing the quantity and the chemical composition of the ashes produced during thermochemical conversion. In turn, the characteristics of these ashes vary depending on the soil conditions where the biomass developed, the combustion technology, operating conditions (temperature, stoichiometry, air staging, and additives) as well as the gas cleaning systems used.

Generally, two types of ashes are produced during biomass combustion in fluidized bed systems, namely bottom ash (BA) and fly ash (FA). Briefly, BA is composed of a mixture of sand particles (mainly quartz) from the original bed, exogenous inorganic components from forest soil, and small rock material present as contaminants. Compared with BA, FA is finer in particle size and richer in inorganic components of the original biomass (TARELHO et al., 2015). The FA and the BA obtained by combustion of biomass in a fluidized bed reactor are classified as industrial waste codes 100101 and 100124, respectively, according to the European List of Wastes (CCDRLVTD, 2004). A waste management approach considers first the strategies to reduce and reuse waste rather than recycling, recovering energy, and treating and correctly disposing thereof (MORAES et al., 2014). However, when valorization of a new material with potential use in specific waste management strategies is required, a well formulated and characterized pre-treatment stage is indispensable to ensure the quality of the final product.

According to Moraes et al. (2004), Rajamma et al. (2015) and Modolo et al. (2017) ash produced from the combustion of biomass like rice husk and forest waste may become technically and environmentally feasible admixtures in construction materials, helping mitigate the environmental impacts associated with ash disposal in landfills.

Natural aggregate consists of a mixture of sand and crushed bedrock or even naturally occurring materials such as unconsolidated sand and gravel. It is a major component of widely used construction materials such as asphalt and concrete, for example (BLEISCHWITZ; BAHN-WALKOWIAK, 2006). The prevalence of quartz enhances the siliceous nature of biomass ash, making it a good candidate to replace natural aggregates in the construction sector or calibrated sand in commercial mortar mixes, for instance (MODOLO et al., 2013; MODOLO, 2014; MODOLO et al., 2015).

Despite such interesting recycling potential, relevant concerns about environmental aspects need to be addressed to ensure that the whole valorization stream of BA and FA is sustainable. In this context, this study 
brings new knowledge about the production of rendering mortars prepared by replacing conventional sands, namely coarse sand (CS) and fine sand (FS) by different dosages of biomass dry BA and FA. The pre-processing of $B A$ and $F A$ was characterized in the effort to reuse these materials as effective partial replacements of natural sand in mortars, and information about the associated environmental aspects was produced to support this recycling strategy.

\section{MATERIALS AND METHODS}

Untreated BA and FA were collected from a $90 \mathrm{MW}$ bubbling fluidized bed combustor (BFBC) in a thermal power plant (TPP) located in central Portugal, where forest biomass composed by eucalyptus bark and logging residues is used as fuel. The operation temperature of the bubbling bed ranges from $800^{\circ} \mathrm{C}$ to $850^{\circ} \mathrm{C}$. BA and FA were collected directly from the ashtray of the BFBC system as shown in Figure 1.

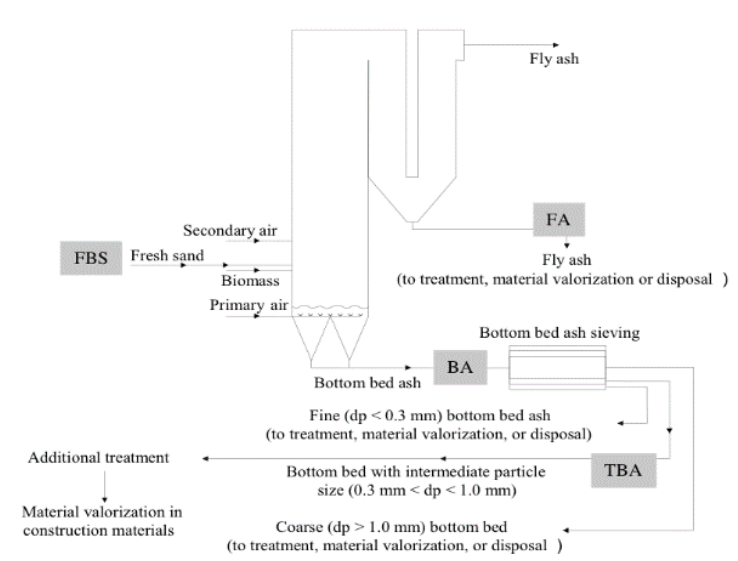

Figure 01 - Representation of the ash flows generated in the bubbling fluidized bed combustor $(\mathrm{BFC})$ including the basic operations implemented for potential valorization

Source: Adapted from Modolo et al. (2015).

Twenty-five tons of BA generated from forest biomass combustion in a BFBC in a pulp and paper company were used in the experimental work. The material was transported from the combustion unit located at the pulp and paper facility to an industrial facility that processes raw material for the construction sector. The facility's operations include the processing of natural sand as aggregate for the construction industry. The goal was treating BA and use the recycled material to replace conventional raw material (natural sand) in industrial mortars. BA was stored for $24 \mathrm{~h}$ and then washed in a shower system with water at a 2:1 liquid to solid ratio. The processing capacity of the industrial facility was 10 ton/h, and the washing effluent was treated by sedimentation to be reused in further washing cycles, reducing the use of water resources. Subsequently the processed material was sieved to a particle size lower than $1000 \mu \mathrm{m}$.

Briefly, FA was used as a replacement to FS as received. However, two different batches of BA were prepared; in both cases the material was sieved $(<2.00 \mathrm{~mm})$ to remove coarse inert impurities (e.g. soil, small rocks, tile fragments) and ensure similar particle size distribution when compared to the CS used. The first BA batch was only sieved to get particle size below $1 \mathrm{~mm}$ and is henceforth termed BA, whereas the second BA batch was washed to reduce soluble salts concentration (e.g., chlorides), and will be termed treated bottom ash (TBA). Portland cement (OPC type II 42.5) was used as binder. According to manufacturer, it has a specific surface area (SSA) of $0.47 \mathrm{~m} 2 / \mathrm{g}$ (Blaine fineness), density of 2.98 $\mathrm{g} / \mathrm{cm} 3$, and the chemical composition indicated in Table 1.

\begin{tabular}{|c|c|c|c|c|c|c|c|}
\hline \multirow{2}{*}{ Parameters } & \multicolumn{7}{|c|}{ Raw Materials } \\
\hline & FA & BA & TBA & FS & & $\mathbf{S}$ & OPC \\
\hline $\begin{array}{c}\mathrm{SiO} 2 \\
\text { (\% wt) }\end{array}$ & 46.30 & 67.2 & 81.34 & 99.4 & & 53 & 20.16 \\
\hline $\begin{array}{l}\mathrm{CaO} \\
(\% w t)\end{array}$ & 11.74 & 8.31 & 4.96 & 0.07 & & 28 & 59.91 \\
\hline $\begin{array}{l}\mathrm{Na2O} \\
(\% \text { wt) }\end{array}$ & 1.24 & 1.15 & 0.63 & 0.03 & & 07 & 0.17 \\
\hline $\begin{array}{l}\mathrm{Al} 2 \mathrm{O} 3 \\
(\% \mathrm{wt})\end{array}$ & 15.26 & 9.97 & 5.11 & 0.00 & & 21 & 4.82 \\
\hline $\begin{array}{l}\mathrm{MgO} \\
(\% \mathrm{wt})\end{array}$ & 2.23 & 1.23 & 0.56 & 0.07 & & 01 & 2.27 \\
\hline $\begin{array}{l}\text { Loss on } \\
\text { ingnition } \\
\text { (\% wt) }\end{array}$ & 7.34 & 3.04 & 3.23 & 0.09 & & 24 & 2.26 \\
\hline $\begin{array}{c}\mathrm{Cl}- \\
(\mathrm{mg} / \mathrm{kg} \mathrm{db})\end{array}$ & $\sim 22 \times 103$ & 472 & 160 & 20 & & 0 & 190 \\
\hline \multicolumn{3}{|c|}{$\mathbf{m m}$} & \multicolumn{5}{|c|}{ (\% wt) } \\
\hline \multirow{6}{*}{$\begin{array}{l}\text { Retalned } \\
\text { material } \\
\text { content } \\
\text { In the } \\
\text { sleZves* }\end{array}$} & 1.000 & & 0 & 10 & 0 & 16 & \\
\hline & 0.500 & See & 86 & 83 & 2 & 50 & \\
\hline & 0.250 & Fig. & 14 & 7 & 75 & 29 & NQ \\
\hline & 0.125 & 3 & 0 & 0 & 18 & 3 & \\
\hline & 0.063 & & 0 & 0 & 4 & 1 & \\
\hline & Quartz (SiO2) & $P$ & $P$ & $P$ & $\mathrm{P}$ & $\mathbf{P}$ & NQ \\
\hline \multirow{3}{*}{$\begin{array}{l}\text { Mineralogy } \\
\text { (by XRD) }\end{array}$} & $\begin{array}{l}\text { Calcite } \\
\text { (CaCO3) }\end{array}$ & $P$ & $P$ & $P$ & ND & ND & NQ \\
\hline & $\begin{array}{c}\text { Larnite } \\
\text { Ca2SiO4 }\end{array}$ & $P$ & ND & ND & ND & ND & NQ \\
\hline & $\begin{array}{l}\text { Microcline } \\
\text { (KAISi3O8) }\end{array}$ & P & $\mathbf{P}$ & $P$ & $\mathrm{P}$ & $\mathbf{P}$ & NQ \\
\hline
\end{tabular}

FA: fly ash; BA: bottom ash; TBA: treated bottom ash; FS: fine sand; CS: coarse sand; OPC: Portland cement; NQ: not quantified; P: present; ND: not detected; db: dry base.

* According to EN 933-1: 2000, Tests for geometrical properties of aggregates, Part 1: Determination of particle size distribution.

Table 01 - Chemical and mineralogical composition of solid mixture componentes determined by X-ray fluorescence spectroscopy (XRF) and X-ray diffraction (XRD) Source: adapted from Modolo et al. (2013); Modolo (2014). 
The chemical composition of TBA, untreated BA, and FA was determined by $X$-ray fluorescence spectroscopy (XRF), while crystalline phases were detected by X-ray diffraction (XRD) (Table 1). Chlorides were evaluated using the argentometric method (Chlorine 4500-Cl-, Chlorine residual Standard Methods Committee 1997). The particle size distribution of natural sands (EN 933-1: 2000, Tests for geometrical properties of aggregates, Part 1: Determination of particle size distribution) and of BA and TBA used as mineral aggregates in mortars are shown in Figure 2. Particle size distribution of FA was determined by laser diffraction due to the small particle size (Figure 3). The analysis was performed using the Fraunhofer method for particles between $0.4 \mu \mathrm{m}$ and $2000 \mu \mathrm{m}$ and polarization intensity differential scattering (PIDS) for lower particle sizes (between $0.4 \mu \mathrm{m}$ and $0.04 \mu \mathrm{m}$ ). Scanning electron microscopy (SEM) equipped with an energy dispersion spectroscopy (EDS) unit was used to characterize the microstructure of raw materials (Figure 4). Gravimetric and differential thermal analyses (TG/DTA) were used to evaluate the amount of unburnt organic components (Figure 5).

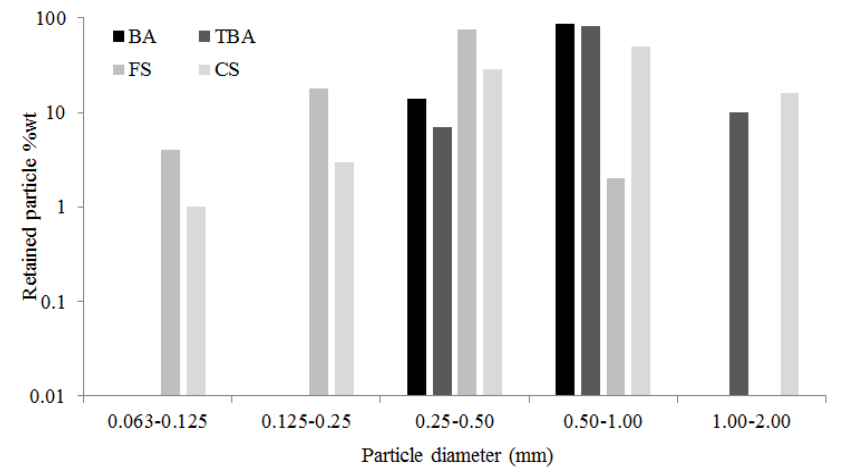

Figure 02 - Particle size distribution of sands and bottom ash (BA) and treated bottom ash (TBA) used in the experiments

Source: Authors

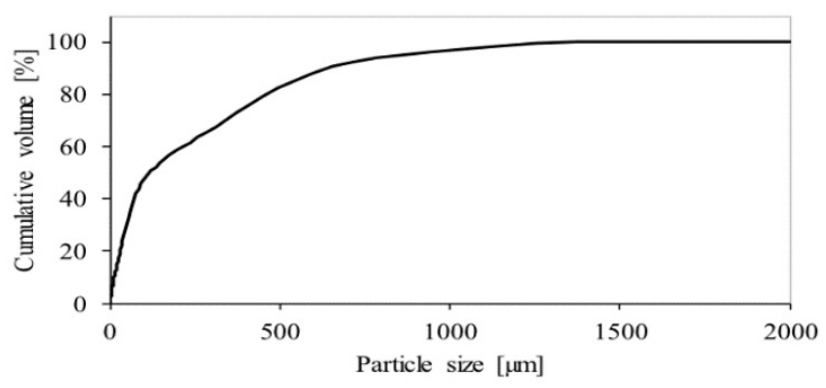

Figure 03 - Particle size distribution of fly ash (FA) as determined by laser diffraction Source: Authors

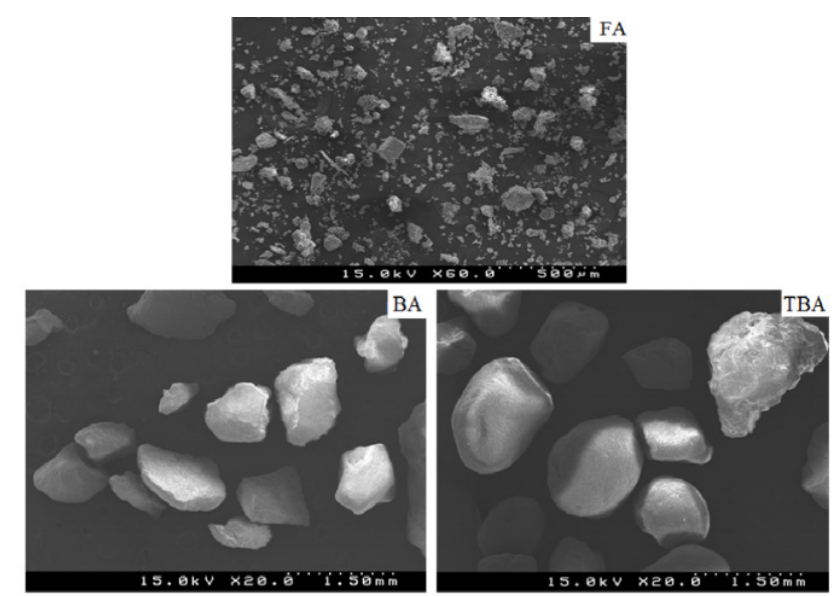

Figure 04 - Scanning electron microscopy (SEM) characterization of ashes Source: Authors

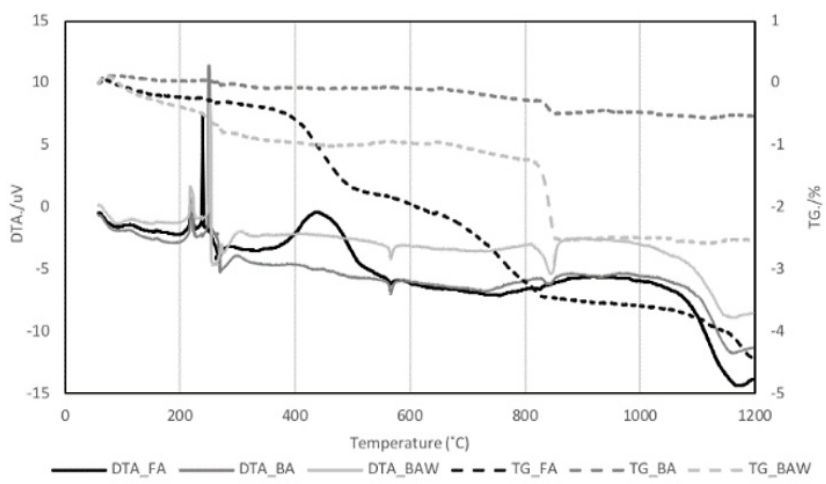

Figure 05 - Gravimetric and differential thermal analyses (TG/DTA) of ashes Source: Authors

The characteristics of mortars produced with up to 20 $\%$ wt. of FA, BA, and TBA as sand replacement were analyzed 180 days into curing. The formulations of mortars are shown in Table 1. A reference mortar (REF) was produced using sand with two different size distributions (CS and FS). Mortars (1:4 binder to aggregate weight ratio) were prepared mixing the solid components inside a plastic bag for 1 min, in order to work with mortars with greater consistency, plasticity and adhesion to resist flow in porous substrates. The mixture was then submitted to mechanical homogenization for $15 \mathrm{~s}$ and left to rest for $1 \mathrm{~min}$. A new mechanical homogenization step ( $1 \mathrm{~min} 15 \mathrm{~s}$ ) ensued. Workability was set at $150 \mathrm{~mm}$ and controlled varying the dosage of water added to the mixtures (Table 2). Three prismatic samples $(40 \times 40 \times 160 \mathrm{~mm})$ were cast according to specific standard methods (EN 1015-11:1999). All samples were placed in a room at controlled relative humidity (65\%) and temperature $\left(23^{\circ} \mathrm{C}\right)$. Compressive strength as well as water absorption by immersion and apparent porosity (EN 1015-10:1999; EN 196-1:2005) were tested at different curing ages. In addition, carbonation extent was determined under natural 
conditions, while the alkali-silica reaction (ASTM C1260: 1994. Standard Test Method for Potential Alkali Reactivity of Aggregates, Mortar-Bar Method), unrestrained shrinkage and weight variation (Cachier du CSTB 2669-4, A3.3: 1993. Certification CSTB unrestrained shrinkage and weight variation) were also evaluated (Table 3). The variance of experimental error was determined using three replicates for each property analyzed.

\begin{tabular}{|c|c|c|c|c|c|c|c|}
\hline & FS & CS & FA & BA & TBA \\
\hline \multicolumn{3}{|c|}{ REF } & 1 & 3 & - & - & - \\
\hline \multicolumn{3}{|c|}{ 10FA } & 0.9 & 3 & 0.1 & - & - \\
\hline \multicolumn{3}{|c|}{ 20FA } & 0.8 & 3 & 0.2 & - & - \\
\hline \multicolumn{3}{|c|}{ 10BA } & 1 & 2.7 & - & 0.3 & - \\
\hline \multicolumn{3}{|c|}{ 10ТВА } & 1 & 2.7 & - & - & 0.3 \\
\hline \multicolumn{3}{|c|}{ 20BA } & 1 & 2.4 & - & 0.6 & - \\
\hline \multicolumn{3}{|c|}{ 20ТВА } & 1 & 2.4 & - & - & 0.6 \\
\hline \multicolumn{3}{|c|}{$10 \mathrm{FA}+10 \mathrm{BA}$} & 0.9 & 2.7 & 0.1 & 0.3 & - \\
\hline \multicolumn{3}{|c|}{ 10FA $+10 \mathrm{TBA}$} & 0.9 & 2.7 & 0.1 & - & 0.3 \\
\hline \multicolumn{3}{|c|}{$20 F A+20 B A$} & 0.8 & 2.4 & 0.2 & 0.6 & - \\
\hline \multicolumn{3}{|c|}{ 20FA+20TBA } & 0.8 & 2.4 & 0.2 & - & 0.6 \\
\hline \multicolumn{7}{|c|}{ Components (\% wt) } & \multirow{2}{*}{$\begin{array}{c}\text { Spread } \\
(\mathbf{m m})\end{array}$} \\
\hline OPC & FS & CS & FA & BA & TBA & Water & \\
\hline 100 & 100 & 300 & - & - & - & 70 & 155 \\
\hline 100 & 90 & 300 & 10 & - & - & 72.5 & 150 \\
\hline 100 & 80 & 300 & 20 & - & - & 73.3 & 150 \\
\hline 100 & 100 & 270 & - & 30 & - & 70 & 140 \\
\hline 100 & 100 & 270 & - & - & 30 & 72.5 & 150 \\
\hline 100 & 100 & 240 & - & 60 & - & 70 & 145 \\
\hline 100 & 100 & 240 & - & - & 60 & 73 & 145 \\
\hline 100 & 90 & 270 & 10 & 30 & - & 72 & 145 \\
\hline 100 & 90 & 270 & 10 & - & 30 & 73.5 & 155 \\
\hline 100 & 80 & 240 & 20 & 60 & - & 72.4 & 155 \\
\hline 100 & 80 & 240 & 20 & - & 60 & 74.5 & 155 \\
\hline
\end{tabular}

Table 02 - Mortar formulations Source: Authors

\begin{tabular}{|c|c|c|c|}
\hline $\begin{array}{l}\text { Product } \\
\text { state }\end{array}$ & Measurements & $\begin{array}{l}\text { Time } \\
\text { (days) }\end{array}$ & Standard \\
\hline Powder & $\begin{array}{c}\text { Grain size } \\
\text { distribution }(\mathrm{mm})\end{array}$ & 0 & EN 933-1: 2000 \\
\hline \multirow[t]{5}{*}{ Fresh } & $\begin{array}{l}\text { Flow table } \\
\text { test }(\mathrm{mm})\end{array}$ & 0 & EN 1015-3:2007 \\
\hline & $\begin{array}{c}\text { Unrestrained } \\
\text { shrinkage }(\mathrm{mm})\end{array}$ & 7,28 & $\begin{array}{c}\text { Cachiers du CSTB } \\
\text { (2669-4): A3.3 }\end{array}$ \\
\hline & $\begin{array}{c}\text { Weight } \\
\text { variation (\%) }\end{array}$ & 7,28 & 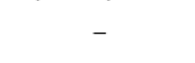 \\
\hline & $\begin{array}{l}\text { Compressive } \\
\text { strength (MPa) }\end{array}$ & $\begin{array}{c}7,28 \\
180\end{array}$ & EN 1015-11:1999 \\
\hline & $\begin{array}{c}\text { Apparent } \\
\text { porosity (\%) }\end{array}$ & $\begin{array}{l}7,28 \\
180\end{array}$ & EN 1015-10:1999 \\
\hline \multirow[t]{5}{*}{ Hardened } & $\begin{array}{c}\text { Water } \\
\text { absorption (\%) }\end{array}$ & $\begin{array}{c}7,28 \\
180\end{array}$ & 0.6 \\
\hline & $\begin{array}{l}\text { Alkali-silica reaction } \\
(\%)\end{array}$ & 1 to 28 & ASTM C1260: 1994 \\
\hline & $\begin{array}{l}\text { Natural carbonation } \\
\text { (na) }\end{array}$ & 180 & $N^{*}$ \\
\hline & $\begin{array}{c}\text { Grain size } \\
\text { distribution }(\mathrm{mm})\end{array}$ & 0 & EN 933-1: 2000 \\
\hline & $\begin{array}{l}\text { Flow table } \\
\text { test }(\mathrm{mm})\end{array}$ & 0 & EN 1015-3:2007 \\
\hline
\end{tabular}

Table 03 - Experimental tests and standards used Source: Authors

\section{ANALYSIS AND DISCUSSION OF RESULTS}

The workability of mortars formulated with distinct dosages of BA, TBA, and FA is shown in Table 2. The water content used to keep the workability of samples constant did not differ significantly compared with the REF formulation, because the physical characteristics of BA or TBA and FA were like those of CS and FS. The negative impact often observed when using an additional volume of water in mortars formulated with finer additions tends to be minimal (SENFF, 2011; SENFF et al., 2014 and SENFF et al., 2015).

Figure 6 shows the apparent porosity and water absorption values of samples cured for up to 180 days. Addition of FA and BA or TBA did not significantly influence the parameters analyzed, and values remained at equivalent levels. This behavior is explained in view of the similar internal porous structure of the hardened matrix (Figure 7). But, during the experiment the values of both properties tended to decrease, as observed in a natural, progressive hydration process. Similar behavior was observed for the carbonation reactions. This highlights the importance of balancing the maximum dosage of FA and BA (or TBA) with adequate dosage water to ensure the expected properties upon curing.

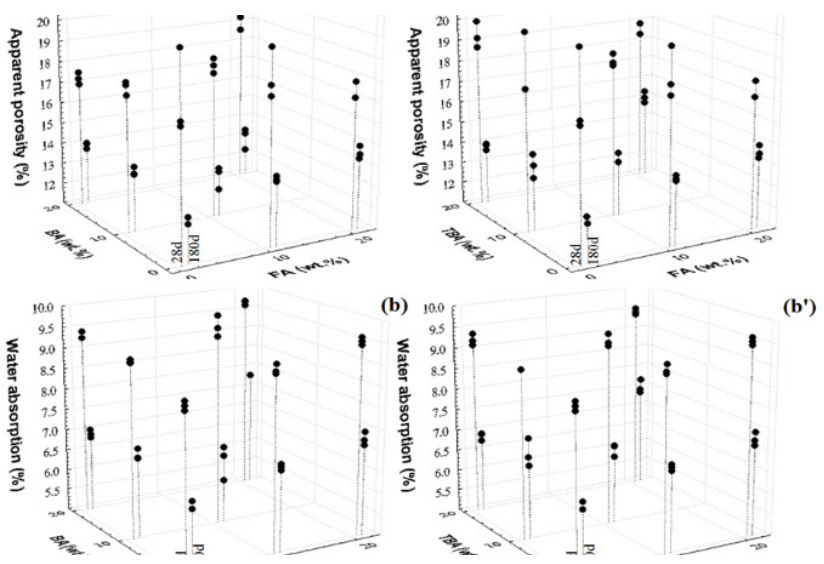

Figure 06 - Apparent porosity (a) and ( $\left.a^{\prime}\right)$ and water absorption (b) and $\left(b^{\prime}\right)$ of mortars cured for 28 and 180 days, respectively

Source: Authors

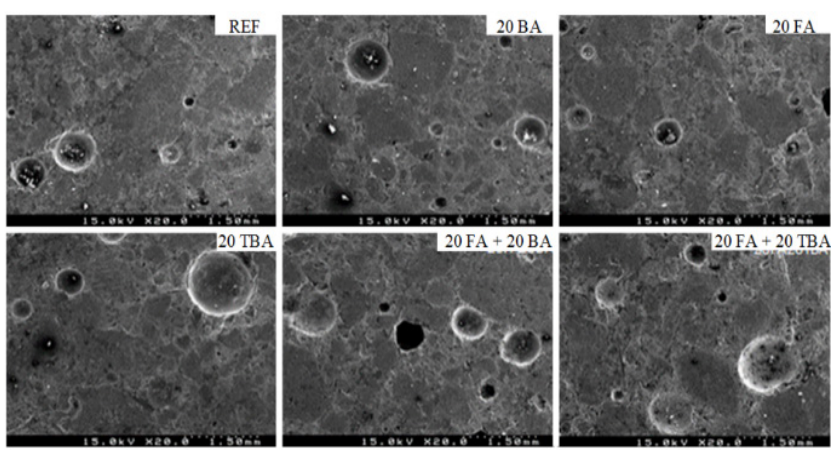

Figure 07 - Scanning electron microscopy (SEM) images of mortars cured for 180 days Source: Authors 
Figure 8 shows the weight variation and the values of unrestrained shrinkage of mortars cured for up to 28 days. A significant weight variation was observed caused by intense loss of water in the early setting period. Loss of water induces the contraction of capillary walls in the microstructure (NAWY, 2001), increasing unrestrained shrinkage. After this period, weight variation diminished indicating equilibrium under room conditions, while unrestrained shrinkage values increased. Such results may also be associated with the carbonation effect that influences shrinkage evolution if relative humidity is maintained between $50 \%$ and $75 \%$ in the curing environment (MEHTA; MONTEIRO, 1993). In addition, these curing settings can compensate for the weight loss caused by the loss of water from the solid structure. These results underscore the importance of balancing the amounts of water for a given dosage of FA or BA in mortar mixtures.
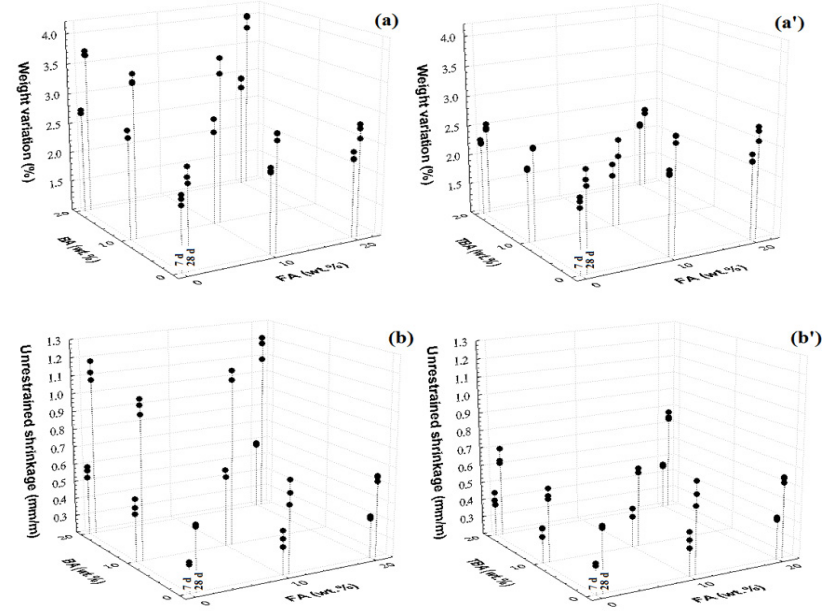

Figure 08 - Weight variation (a) and unrestrained shrinkage (b) of mortars cured for 7 and 28 days Source: Authors

Figure 9 shows the compressive strength of mortars containing up to $20 \%$ wt. of BA, TBA, or FA. Although the compressive strength of these mortars was not improved significantly, the results remained at essentially the same levels compared to the results observed for the REF sample.

These findings may be explained in view of the internal porosity of mortars as discussed. A pozzolanic reaction induced by FA can be disregarded, because the material did not express any appreciable pozzolanic activity. Besides, the cement content and the dosage of water used in test samples did not differ significantly from the amounts used in the REF sample, which may also explain the similarity in results. In addition, a filler effect of FA does not seem strong enough to enhance the compressive performance.
The increase in compressive strength of all samples observed only in the earlier ages (up to 28 days) is a natural phenomenon in hydration. The additional increase in compressive strength values observed after this period is of minor significance. Again, the results confirm the apparent porosity and water absorption values previously mentioned.
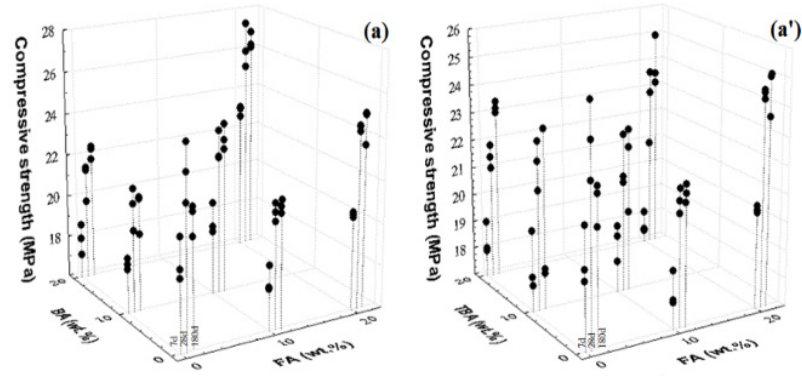

Figure 09 - Compressive strength (a) and ( $\left.a^{\prime}\right)$ values of mortars cured up to 180 days Source: Authors

The expansion of mortar samples containing distinct dosages of FA e BA due to alkali-silica reaction is shown in Figure 10 . The potentially reactive aggregates, like those used in REF, are not stable in alkaline medium and tend to produce an expansive gel because of this reaction over time, which is responsible for the deterioration of the material (MEHTA; MONTEIRO, 1993, SENFF et al., 2014). The expansion values of all mortars formulated with FA and BA exhibited similar behavior to that of REF, exceeding the admissible limit $(0.2 \%$ on day 28$)$, as defined in the standard used to assess the parameter (ASTM C1260. Standard Test Method for Potential Alkali Reactivity of Aggregates - Mortar-Bar Method). The absence of pozzolanic activity from FA and BA may explain the behavior observed.

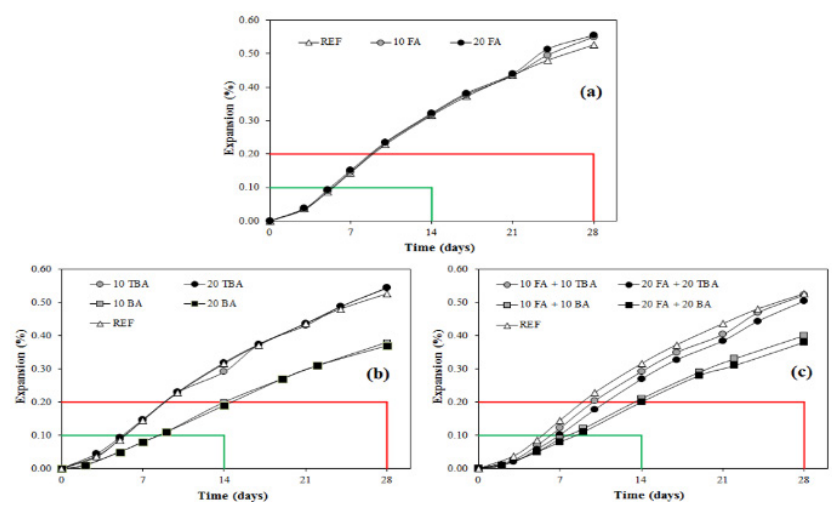

Figure 10 - Expansion of samples prepared with mortars cured for up to 28 days Source: Authors

Figure 11 shows the influence of FA, BA, and TBA on the progress of carbonation reactions of mortars cured for up to 180 days. This parameter was visually observed. 
In general, carbonation depends on available atmospheric $\mathrm{CO} 2$ that reacts with the calcium hydroxide formed during hydration and the porous structure of the material generated (RAMACHANDRAN; ZHANG, 1986; SENFF et al., 2014). Besides the microstructural change, a dimensional instability in the hardened material could be also observed by Ramachandran and Zhang (1986). As the samples tested in this work have similar extent of the carbonation reaction, the results confirm the absence of pozzolanic potential or microfiller effect of FA, which was able to reduce the entry of $\mathrm{CO} 2$ into the structure. The structural contractions observed 180 days into curing and the apparent porosity and water absorption values are useful parameters to predict such behavior.
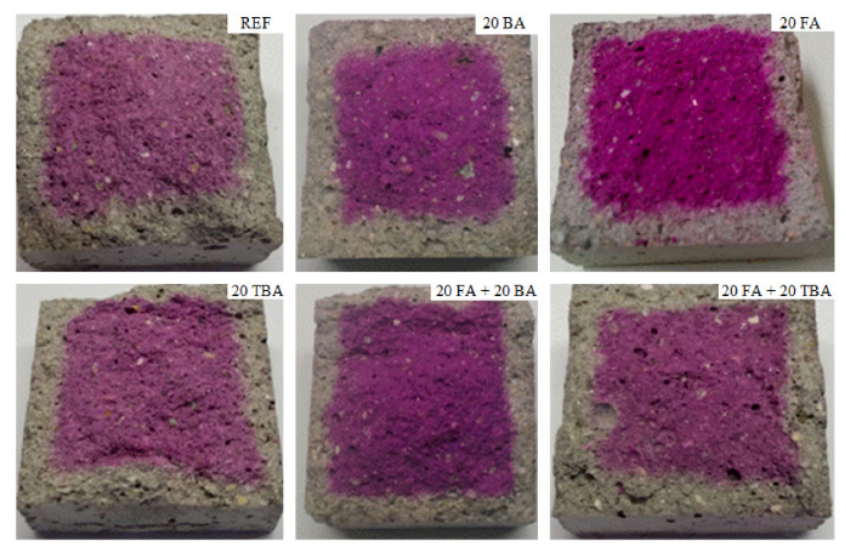

Figure 11 - Natural carbonation of mortars produced with incorporation of BA, TBA and FA after 180 days.

Source: Authors

The valorization of BA and FA produced during biomass combustion in TPPs was discussed in this study concerning their use as aggregate in mortar formulations in substitution of natural quartz-sand.

In fact, an important environmental aspect in the development of construction materials is the extraction of potentially scarce natural resources. On the other hand, BA is an industrial waste common in power production based on the combustion of a renewable resources such as biomass. The proper management and recycling of such waste may help avoid a negative environmental impact, especially because it will not be disposed of in landfills.

Based on the recycling potential of $B A$ and its use to replace natural sand, the process developed in the present study advances a perspective of solution with potential to reduce the extraction of natural sand, a raw natural resource, and mitigates the environmental impact of the disposal of the ash (a waste) in industrial landfills.
This perspective meets the principles of industrial ecology and circular economy, mitigating environmental impacts caused by industrial activity.

However, the industrial application of such a solution depends on how far the associated environmental aspects, namely its benefits or drawbacks, are well characterized and properly understood. In this sense, it is important to characterize the operations and processes involved and the material and energy flows of such a solution concerning the upstream processing of both materials, that is, natural sand and $B A$.

Although the quantitative analysis of such detailed environmental assessment is beyond the scope of this work, a simplified qualitative approach to identify the most relevant treatment processes and operations applied to BA was developed here based on field practice expertise. For that purpose, Figure 13 shows a simplified material cycles (MCs) of the natural sands used by default as aggregates in the construction materials and that of the BA used.

An important environmental aspect observed in MC1 (sand handling and transport) and MC2 (BA handling and transport) concerns the emission of particulate matter to the atmosphere during handling and transportation of these materials.

However, considering the intrinsic characteristics of the waste (BA) (color, particle size distribution, trace levels of salts such as chlorides), in the steps preceding its effective recycling, the waste should be kept in an appropriate place as a means to prevent the contamination with soil and other materials stored nearby. Figure 12-a shows the storage and management site of the raw material at the sand treatment plant. In the treatment of BA (MC3), energy and water consumptions could increase since the washing of BA has to be performed with the conveyor belt at the minimum speed to ensure the removal of soluble salts. It was also possible to observe that a high amount of particulate material is emitted to the atmosphere when the BA is introduced at the inlet (Figure 12-c and 12-d) of the washing unit. This is termed temporary impact, and in this case, it may affect air quality even if for a short period of time (e.g. few hours) (SANCHES, 2013). This is not observed during the conventional sand washing process. Finally, it was observed that the washing of BA increases the level of suspended solids in the washing effluent, as shown in the settling tank (Figure 12-f), thus increasing the needs of this wastewater treatment. 

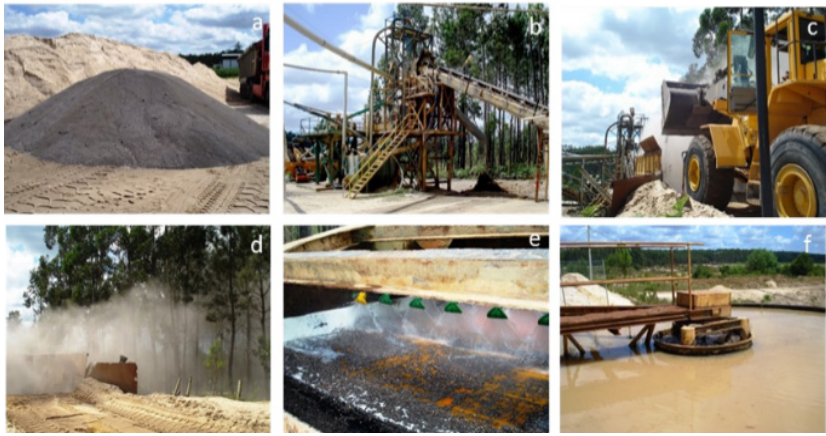

Figure 12 - Treatment of BA for recycling in mortars. MC1: material cycle 1 (conventional sand); MC2: material cycle 2 (BA generation); MC3: material cycle 3 (BA treatment and shipping to recycling); (a) BA storage; (b) conveyor belt material and power control unit; (c) BA introduction in washing system; (d) dust/particulate matter emission from BA; (e) water sprinkler system (showers); and (f) settling system for solids after BA washing Source: Authors

\section{CONCLUSIONS}

This study presents a comparative analysis of the production of rendering mortars by replacing conventional sands, namely CS and FS, by different dosages of biomass BA and FA. The volumes of water used to keep the same workability of the distinct mortar samples were not significantly different from the amounts used to prepare the REF formulation. However, the addition of BA and FA slightly influenced apparent porosity and water absorption of mortars. Compressive strength was not improved significantly when using BA or $F A$, remaining at the same level as in the REF mortar sample. The absence of pozzolanic action from FA and BA increased compressive strength of mortars beyond the admissible limit due to an alkali-silica reaction, though the extent of the carbonation reaction remained unchanged.

Considering the environmental aspect observed in $M C 1$, it relevant to assess the impact caused by emission of particulate matter from the handling of these materials. The pre-processing operations of the ashes have to be properly characterized in the effort to reuse BA and FA as effective replacements of natural sand in mortars, and the associated environmental aspects should be further investigated to support this recycling strategy.

\section{ACKNOWLEDGMENT}

The authors thank Foundation for Science and Technology (FCT- Portugal) for the financial support (SFRH/BD/75182/2010 - PhD grant) and CNPq for the financial support given as first author's grant, CNPq Productivity Research Scholarship (Process 307755/2018-5), and CNPq for the grant Technological Development and Innovative Extension-DT.Guilherme Ascensão's collaboration in this work was performed before his integration in the NEW-MINE project funded by the European Union's EU Framework Programme for Research and Innovation Horizon 2020 under Grant Agreement No 721185 - http://new-mine.eu/. The authors also thank project UID/AMB/50017/2013POCl-01-0145-FEDER-007638 (CESAM) through national funds, and the co-funding by the FEDER, within the PT2020 Partnership Agreement and Compete 2020. Thanks to Portuguese Foundation for Science and Technology (FCT)/Ministry of Science, Technology and Higher Education (MCTES) for the financial support to CESAM (UIDP/50017/2020+UIDB/50017/2020) through national funds

\section{REFERENCES}

BLEISCHWITZ, R., BAHN-WALKOWIAK, B. Sustainable developed in European aggregate industry - A case for sectoral strategies. Environmental and Energy, Germany, 2006.

CALLEJÓN-FERRE A. J., CARREÑO-SÁNCHES J., SUÁREZMEDINA F. J. PÉREZ-ALONSO, J., VELÁSQUEZ-MARTÍ, B. Prediction models for higher heating value based on the structural analysis of the biomass of plant remains from the greenhouses of Almería (Spain). Fuel, v. 116, p. 377-387, 2014.

CCDRLVTD. Decrete n.o 209/2004. Portuguese legislation about the European list of wastes in accordance with Commission Decision 2000/532/EC of 3 May 2000 replacing Decision 94/3/EC establishing a list of wastes pursuant to Article 1(a) of Council Directive 75/442/EEC on waste and Council Decision 94/904/EC establishing a list of hazardous waste pursuant to Article 1(4) of Council Directive 91/689/EEC on hazardous waste.

CHEAH, C. B., RAMLI, M. Mechanical strength, durability and drying shrinkage of structural mortar containing HCWA as partial replacement of cement. Construction and Builiding Materials, v. 30, p. 320-329, 2012.

DAHL, O., NURMESNIEMI, H., PÖYKIÖ, R., WATKINS, G. Comparison of the characteristics of bottom ash and fly ash from a medium-size (32MW) municipal district heating plant incinerating forest residues and peat in fluidised-bed boiler. Fuel Processing Technology, v. 90, p. 871-878, 2009.

EN 1015-10. Methods of test for mortar for masonry Part 10: Determination of dry bulk density of hardened mortar, 1999.

EN 1015-11. Methods of test for mortar for masonry - Part 11: Determination of flexural and compressive strength of hardened mortar, 1999.

EN 1015-3. Methods of test for mortar for masonry: 
determination of consistence of fresh mortar (by flow table), 2007.

EN 933-1. Tests for geometrical properties of aggregates, Part 1: Determination of particle size distribution, 2000. HINOJOSA, M. J. R., GALVÍN, A. P., AGRELA, F., PERIANES, M., BARBUDO, A. Potential use of biomass ash as alternative construction material: Conflictive Chemical parameters according to Technical regulations. Fuel, v. 128, p. 248-259, 2014.

HÖJER, M., AHLROTH, S., DREBORG, K. H., EKVALL, T., FINNVEDEN, G., HJELM, O., HOCHSCHORNER, E., NILSSON, M., PALM, V. Scenarios in selected tools for environmental systems analysis. Journal of Cleaner Production, v. 16, p. 1958-1970, 2008.

LABRINCHA, J. A., MARQUES, J. I., HAJJAJI, W., SENFF, L., ZANELLI, C., DONDI, M., ROCHA, F. Novel inorganic products based on industrial wastes. Waste and Biomass Valorization, v. 5, p. 385-392, 2014.

MEHTA, P. K., MONTEIRO, P. J. M. Concrete - microstructure, properties, and materials, McGraw-Hill, New York, 1993.

MODOLO R.C.E. Valorization of solid wastes from cellulose and paper industry, PhD thesis, University of Aveiro, Aveiro, Portugal, 2014.

MODOLO, R. C. E., FERREIRA V. M., TARELHO, L. A., LABRINCHA, J. A., SENFF, L., SILVA, L. Mortar formulations with bottom ash from biomass combustion. Construction and Building Materials, v. 45, p. 275281, 2013.

MODOLO, R. C. E., SENFF, L., FERREIRA, V. M. TARELHO, L. A. C., MORAES, C. A. M. Fly ash from biomass combustion as replacement raw material and its influence on the mortars durability. Journal of Material Cycles and Waste Management, v. 11, p. 1-10, 2017.

MODOLO, R. C. E., SILVA, T., SENFF, L., TARELHO, L. A. C., LABRINCHA, J. A., FERREIRA, V. M., SILVA, L. Bottom ash from biomass combustion in BFB and its use in adhesive-mortars. Fuel Processing Technology, v.129, p. 192-202, 2015.

MORAES, C. A. M., FERNANDES, I. J., CALHEIRO, D., KIELING, A. G., BREHM, F. A., RIGON, M. R., FILHO, J. A. B., SCHNEIDER, I. A. H., OSORIO, E. Review of the rice production cycle: By-products and the main applications focusing on rice husk combustion and ash recycling. Waste Management and Research, v. 32, p. 1034-1048, 2014.

NAWY, E. G. Fundamentals of high-performance con-

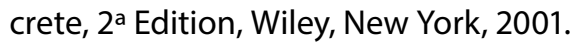

OBERNBERGER, I., BIEDERMANN, F., WIDMANN, W.,
RIEDL, R. Concentrations of inorganic elements in biomass fuels and recovery in the different ash fractions. Biomass and Bioenergy, v. 12, p. 211-224, 1997. PALŠAUSKAS, M., PETKEVIČIUS, S. A new approach to renewable energy: new mixed biomass pellets. Journal of Food, Agriculture and Environment, v. 11, p. 798-802, 2013.

RAJAMMA, R., SENFF, L., RIBEIRO, M. J., LABRINCHA, J. A., BALL, R. J., ALLEN, G. C., FERREIRA, V. M. Biomass fly ash effect on fresh and hardened state properties of cement based materials. Composites Part B, v. 77, p. 1-9, 2015. RAMACHANDRAN, V. S., ZHANG, C. Influence of CaCO3 on hydration and microstructural characteristics of tricalcium silicate. II Cemento, v. 83, p. 129-152, 1986.

SÁNCHEZ, L. E. Avaliação de Impacto Ambiental: conceitos e métodos, $2^{\text {a }}$ edition, Oficina de Textos, São Paulo, 2013.

SENFF L., HOTZA D., LABRINCHA J.A. Effect of lightweight aggregates addition on the rheological properties and the hardened state of mortars. Applied Rheology, v. 21, p. 1-8, 2011.

SENFF, L., MODOLO, R. C. E., ASCENSÃO, G., HOTZA, D., FERREIRA, V. M., LABRINCHA, J.A. Development of mortars containing superabsorbent polymer. Construction and Building Materials, v. 95, p. 575-584, 2015.

SENFF, L., MODOLO, R. C. E., SILVA, A. S., FERREIRA, V. M., HOTZA, D., LABRINCHA, J. A. Influence of red mud addition on rheological behavior and hardened properties of mortars. Construction and Building Materials, v. 65, p. 84-91, 2014.

SENFF, L., TOBALDI, D. M., LEMES-RACHADEL, P., LABRINCHA, J. A., HOTZA, D. The influence of TiO2 and $\mathrm{ZnO}$ powder mixtures on photocatalytic activity and rheological behavior of cement pastes. Construction and Building Materials, v. 65, p. 191-200, 2014.

STEENARI, B. M., FEDJE, K. K., Addition of kaolin as potassium sorbent in the combustion of wood fuel - Effects on fly ash properties. Fuel, v. 89, p. 2026-2032, 2010. TARELHO, L. A. C., TEIXEIRA, E. R., SILVA, D. F. R., MODOLO, R. C. E. LABRINCHA, J. A., ROCHA, F. Characteristics of distinct ash flows in a biomass thermal power plant with bubbling fluidised bed combustor. Energy, v. 90, p. 387-402, 2015. VASSILEV, S. V., BAXTER, D., ANDERSEN, L. K, VASSILEVA, C. G. An overview of the composition and application of biomass ash - Part 2. Fuel, v.105, p. 19-39, 2013.

ZOBEL, T., ALMROTH, C., BRESKY, J. BURMAN, J-O. Identification and assessment of environment aspects in an EMS context: an approach to a new reproducible method based on LCV methodology. Journal of Cleaner Production, v. 10, p. 381-396, 2002. 


\section{AUTORES}

http://orcid.org/0000-0001-7088-2502

REGINA CÉLIA ESPINOSA MODOLO, Dra. | Ciências e Engenharia do Ambiente | Universidade do Vale do Rio dos Sinos (UNISINOS-RS) | PPG's em Engenharia Civil e Engenharia Mecânica | São Leopoldo, RS, Brasil | Av. Unisinos, 950, Bairro Cristo Rei - RS, 93022-750 | email: reginaem@unisinos.br

https://orcid.org/0000-0002-6003-4486

GUILHERME ASCENSÃO, Dr. | Engenharia de Materiais | Universidade de Aveiro (UA-PT) | Departamento de Engenharia Civil | Aveiro, Portugal, 3810-193 | email: guiIhermedascensao@hotmail.com

http://orcid.org/0000-0002-3196-2128

LUCIANO SENFF, Dr. | Ciência e Engenharia de Materiais/ | Universidade Federal de Santa Catarina (UFSC - SC)| Departamento de Engenharias da Mobilidade | Joinville SC, Brasil, 89218-000 | email: Isenff@gmail.com

http://orcid.org/0000-0001-8790-3023

FRANCISCO ROGER CARNEIRO RIBEIRO, M.Sc. | Engenharia Civil | Universidade do Vale do Rio dos Sinos (UNISINOS-RS) http://orcid.org/0000-0001-8002-0682

ANTÓNIO SANTOS SILVA, Dr. | Engenharia Civil | Departamento de Materiais - Laboratório Nacional de Engenharia Civil | Lisboa, Portugal, 1700-066 | email: ssilva@Inec.pt

http://orcid.org/0000-0001-7295-2826

CARLOS ALBERTO MENDES MORAES, Dr. | Ciência dos Materiais | Universidade do Vale do Rio dos Sinos (UNISINOS-RS) | PPG's em Engenharia Civil e Engenharia Mecânica | São Leopoldo, RS, Brasil | Av. Unisinos, 950, Bairro Cristo Rei RS, 93022-750 | email: cmoraes@unisinos.br

\section{COMO CITAR ESTE ARTIGO}

MODOLO, Regina Célia Espinosa; ASCENSÃO, Guilherme; SENFF, Luciano; RIBEIRO, Francisco Roger Carneiro; TARELHO, Luis António da Cruz; FERREIRA, Victor Miguel. LABRINCHA, João António; SILVA, António Santos; MORAES, Carlos Alberto Mendes. Recycling Of Ashes From Biomass Combustion As Raw Material For Mortars. MIX Sustentável, [S.I.], v. 7, n. 2, p. 137-146, abr. 2021. ISSN 24473073. Disponível em:<http://www.nexos.ufsc.br/index.php/mixsustentavel>. Acesso em: dia mês. ano. doi:https://doi. org/10.29183/2447-3073.MIX2021.v7.n2.137-146.

DATA DE ENVIO: 28/09/2020

DATA DE ACEITE: $17 / 01 / 2021$

http://orcid.org/0000-0003-0385-5621

LUIS ANTÓNIO DA CRUZ TARELHO, Dr. | Engenharia do Ambiente | Universidade de Aveiro (UA-PT) | Departamento de Ambiente e Ordenamento and Centre for Environmental and Marine Studies (CESAM) | Aveiro, Portugal, 3810-193| email: Itarelho@ua.pt

http://orcid.org/0000-0002-6295-1333

VICTOR MIGUEL FERREIRA, Dr. | Ciência e Engenharia de Materiais| Universidade de Aveiro (UA-PT) | Departamento de Engenharia Civil | Aveiro, Portugal, 3810-193 | email: victorf@ua.pt

http://orcid.org/0000-0003-1768-718X

JOÃO ANTÓNIO LABRINCHA, Dr. | Engenharia de Materiais e Cerâmica|Universidade de Aveiro (UA-PT) |Departamento de Engenharia de Materiais e Cerâmica | Aveiro, Portugal, 3810-193 | email: jal@ua.pt 